\title{
Gas Chromatography-Mass Spectrometry Analysis of some Organochlorine Pesticides in Cowpea from South- South of Nigeria
}

\author{
Emmanuel Eimiomodebheki Odion ${ }^{1, *}$, Stella Folajole Usifoh ${ }^{2}$, Okhumen Joel Abolagba $^{3}$, \\ John Oamen Igene ${ }^{4}$, Cyril Odianose Usifoh ${ }^{1}$ \\ ${ }^{1}$ Department of Pharmaceutical Chemistry, University of Benin, Nigeria. \\ ${ }^{2}$ Department of Clinical Pharmacy and Pharmacy Practice, University of Benin, Nigeria. \\ ${ }^{3}$ Department of Aquaculture and Fisheries Management, University of Benin, Nigeria. \\ ${ }^{4}$ Department of Food Science Technology, University of Benin, Nigeria.
}

Authors' Contributions

1 Conception \& Study Design, Data Collection

\& Processing, Data Analysis and/or Interpretation, Drafting of Manuscript.

2 \& 4 Conception \& Study Design, Data Analysis and/or Interpretation, Drafting of Manuscript, Critical Review.

3 \& 5 Conception \& Study Design, Data Collection \& Processing, Data Analysis and/or Interpretation, Critical Review.

\section{Acknowledgement}

\section{Article info.}

Received: July 10, 2020

Accepted: December 09, 2020

Funding Source: TETFUND/NRF2014

Conflict of Interest: Nil

Cite this article: Odion EE, Usifoh SF Abolagba OJ, Igene JO, Usifoh CO. Gas Chromatography-Mass Spectrometry Analysis of some Organochlorine Pesticides in Cowpea from South-South of Nigeria. RADS J Pharm

Pharm Sci. 2020; 8(3):134-140.

*Address of Correspondence Author: emmanuel.odion@uniben.edu

\section{A B S TR ACT}

Background: Organochlorine pesticides used illegally in the storage of cowpeas by some farmers to prevent attack by weevils were known to affect the health of human adversely.

Objectives: This study determined the mean concentration of aldrin, o, $\mathrm{p}^{\prime}$ DDT, endosulfan, heptachlor epoxide and $\mathrm{y}-\mathrm{HCH}$ collected from some markets in South-South of Nigeria, compared these concentrations with set standards and ascertained the incidence of occurrence in cowpeas.

Methods: Forty-eight samples of cowpeas were randomly collected from local markets, identified, authenticated, extracted with dichloromethane using Soxhlet apparatus, cleaned-up with silica gel and analysed in a GC-MS using Restek column.

Results: The mean concentration of aldrin $(445.08 \pm 6.43) \mu \mathrm{g} / \mathrm{kg}$, heptachlor epoxide $(188.84 \pm 3.42) \mu \mathrm{g} / \mathrm{kg}$, o,p'-DDT $(182.24 \pm 5.13) \mu \mathrm{g} / \mathrm{kg}$, endosulfan $(142.94 \pm 2.05) \mu \mathrm{g} / \mathrm{kg}$ and $\mathrm{\gamma}-\mathrm{HCH}(243.90 \pm 4.01) \mu \mathrm{g} / \mathrm{kg}$ in some markets were high and above the maximum residual limit.

Conclusion: Organochlorine pesticides are used in most of the markets in south-south Nigeria for the preservation of cowpeas and in some cases, two or more were detected in a given sample, which could be due to the addition of a combination of pesticides. The need for regular monitoring by regulatory agencies and for sensitisation of both the farmers and merchants on the danger of using these pesticides in cowpeas preservation is therefore germane.

Keywords: Gas chromatography-mass spectrometry, South-south Nigeria, Cowpea, Organochlorine pesticides, Restek column.

\section{INTRODUCTION}

Pesticides are important in seeds storage and also in the protection of man and his domestic animals from vectors of infectious diseases [1]. One of the broad classifications includes organochlorine, a widely used multipurpose chlorinated hydrocarbon [2], with inherent properties such as environmental persistency, fat-loving and bio-accumulation [3]. 
Acute concentrations of organochlorine affect the nervous system while chronic doses encourage the liver tissues to release metabolising enzymes [4]. It interacts with endocrine receptors such as androgen and oestrogen [5]. and exposure leads to severe health effect in living things [6]. These have resulted in its ban in many countries, while others allow it to be used for restricted purposes [7].

Commonly used organochlorine pesticides (OCPs)resist chemical and microbiological breakdown [8]. It can be absorbed across the skin, from the lungs and intestinal lining [9]. The biliary and urinary pathways are responsible for its excretion in human [10], while in lactating mother these OCPs are excreted in maternal milk [11] and extreme starvation.

Sharma and co-workers have evaluated the presence of OCPs in foods and the environment by different methods [12]. Sosan and co-worker in 2015 [3] and Olufade and co-worker 2014 [13]. have used gas chromatography (GC) in the analysis for OCPs. This study intends to use GC-MS in its analysis with one of the recently introduced columns, Restek Rtx-CL column, with unique selectivity for separation of OCPs and having advantage of a quicker time of run, differentiating times of retention and elution orders in the confirmatory analysis as this column also fulfilled the criteria by U.S. EPA. Optimal performance by the column involves conditioning at maximum temperature to obtain the desired baseline level.

Vigna unguiculata (family: Fabaceae), known as cowpeas is a leguminous plant that has its origin from Africa [14], and popularly cultivated in Middle East, Asia and parts of North America [15]. It is more or less a staple food in the southern part of Nigeria, hence this study was limited to the states in SouthSouth of Nigeria.

There is paucity of information on the concentration of OCPs in cowpeas from the south-south states of Nigeria. Thus the aim of this study was to evaluate the mean concentration of aldrin, o,p'-DDT, endosulfan, heptachlor epoxide and $\mathrm{y}-\mathrm{HCH}$ in cowpea collected from south-south states and to compare these concentrations with set standards and ascertain the incidence of occurrence of these pesticides in cowpeas.

\section{MATERIALS AND METHODS}

\section{Study Area and Sample Collection}

Cowpeas were obtained from local
Bayelsa (Swali, Warehouse, Yenagoa), Cross river (Esuk, Ikom main market, Watt), Delta (Igbudu, Jakpa, Main market), Edo (Aduwawa, Agenebode, Ekehuan, Illushi, Lagos street), Rivers (Oil mill, Rumukoro, Rumukuta). A total of 48 samples (three from each market) were obtained and an estimated $1.2 \mathrm{~kg}$ of cowpea sample were separately collected at random from each location with sterile polyethene ziplock bags, before taken to the Pesticide Research Laboratory of the Faculty of Pharmacy, University of Benin, Benin City, Nigeria and stored immediately at a temperature of $40 \mathrm{C}$ until analysed.

\section{Reagents and Chemicals}

All reagents used for this study were of high standard and included analytical grade of anhydrous sodium sulphate (Na2SO4) and silica gel was obtained from Oxford laboratory (India). Dichloromethane and acetone were supplied by Labscan (Sigma- Aldrich, USA). In-house purification was used to obtain the distilled water for analysis. Reference standard pesticides for aldrin, o,p'-DDT, endosulfan, heptachlor epoxide and $\mathrm{y}-\mathrm{HCH}$ were obtained from SigmaAldrich Germany.

\section{Quality Testing of Cowpea Sample}

The freshly harvested cowpea sample used for the recovery experiment was obtained from the Faculty of Agriculture Farm, University of Benin, Benin City, Nigeria.

\section{Sample Preparation, Extraction and Clean-up}

Hand-picked $50 \mathrm{~g}$ cowpeas seeds were pulverised using a milling machine (Victoria), after which the powder was properly mixed and $10 \mathrm{~g}$ sample was weighed into a white baff which was placed in Whatman pre-extraction thimble of a Soxhlet apparatus, based on the method described by [16], extraction was done by dichloromethane $(150 \mathrm{ml})$ at $60^{\circ} \mathrm{C}$ for $3 \mathrm{hrs}$. Rotary evaporator was used to reduce the extract to $5 \mathrm{ml}$ at $40{ }^{\circ} \mathrm{C}$ and subsequently dried with sodium sulphate $(5 \mathrm{~g})$.

Clean-up was done using 160-200 mesh size activated silica gel (analytical grade) with dichloromethane. The combined eluent was dried in rotary evaporator and reconstituted with $1 \mathrm{ml}$ dichloromethane for analysis (GC-MS). Cowpeas without pesticides were spontaneously analysed.

\section{GC-MS Conditions}

The GC-MS model QP-2010 (Shimadzu) with spitless/split injector and equipped connected to 
Restek Stx-CL pesticide column (Length $30 \mathrm{~m}$, $0.25 \mathrm{~mm}$ I.D, $0.25 \mu \mathrm{m}$ thickness) was used to identify the target OCPs. An energy of $70 \mathrm{eV}$ was used to generate the mass spectra by monitoring ions $(\mathrm{m} / \mathrm{z}=$ 50 - 450) in full-scan and selected recording mode (SIM). Injection volume and temperature $1 \mu \mathrm{L}$ and $250{ }^{\circ} \mathrm{C}$ respectively. Ion and interface source temperature were $200^{\circ} \mathrm{C}$ and $250{ }^{\circ} \mathrm{C}$ respectively, injection and detection temperatures were adjusted to $250{ }^{\circ} \mathrm{C}$. The column temperature was set at $60{ }^{\circ} \mathrm{C}$ and increased immediately at the rate of $10^{\circ} \mathrm{C} / \mathrm{min}$. to $180{ }^{\circ} \mathrm{C}$ where it was held for 2 min., this was increased by $15^{\circ} \mathrm{C} / \mathrm{min}$., to $280^{\circ} \mathrm{C}$, and held finally for $4 \mathrm{~min}$.

\section{Quantification, Identification and Calculations of Organochlorine in Cowpea}

External standard method was used to determine the concentrations of aldrin, ortho, para'-dichlorodiphenyl-trichloro-ethane (o,p'-DDT), endosulfan, heptachlor epoxide and gamma-lindane $(\mathrm{y}-\mathrm{HCH})$ in cowpeas, by extrapolating the peak obtained to those obtained from standard calibration curve. Linearity was obtained from the correlation coefficient of the calibration curve. Retention time was also used in the identification of the pesticides obtained from the analysis with that of the standards according to OJ/EU (2004) [18]. This was further confirmed by setting the mass spectrometry in the SIM mode.

The limits (LOD) and limit of quantification (LOQ) of the method were obtained from the signal-to-noise ratios, with numerical values of 3.0 and 10.0. These were carried out experimentally by subjecting spiked samples to sample preparation and clean-up. Background noise was approximately determined by analysis of blank samples. Recovery experiment was estimated by extracting spiked blank and comparing the values with the quantity of pesticides that were used to spike the blank cowpea. Precision expressed as percentage relative standard deviation (\% RSD) was evaluated by analysing samples in triplicate.

\section{RESULTS}

GC analysis result were evaluated based on the peak area for each of the analyte, while the quantification of the unknown concentration was obtained by interfering the peak areas into the calibration graph formulae. From Table 1, correlation coefficients (R2) of this study are above 0.9900 , indicating good linearity for the detector used in the quantification of the pesticides. The relative standard deviation of the migratory time was between $3.2 \%-7.5 \%$, showing the method to be reproducible. The detection limit (LOD) $0.14 \mu \mathrm{g} / \mathrm{kg}$, implying that GC could detect OCPs in the cowpeas matrix at this concentration and the quantity of pesticides was as low as $0.47 \mu \mathrm{g} / \mathrm{kg}$.

It was observed that the retention time for the pesticides used for this study ranged from 3.84 to 6.43 min (Table 2). This time is shorter than what was observed in a previous work executed [13] where the column used produced a longer retention time of about 20 min. Restek Stx-CL Pesticides column used in this study show specificity for organochlorine and shorter retention time. This unique selectivity and combination with mass spectroscopy prevented or reduced interference from the matrix and encouraging a high throughput.

The highest mean concentrations of aldrin and heptachlor were observed in Agenebode $(445.08 \pm 6.43) \mu \mathrm{g} / \mathrm{kg}$ and Illushi $(188.84 \pm 3.42) \mu \mathrm{g} / \mathrm{kg}$ markets. The highest mean concentration of endosulfan (182.24 \pm 5.13$) \mu \mathrm{g} / \mathrm{kg}$ was detected in Tiam market, while Oil mill market and Main markets had the highest mean concentrations of heptachlor $(142.94 \pm 2.05) \mu \mathrm{g} / \mathrm{kg}$ and $\mathrm{\gamma}-\mathrm{HCH}(243.90 \pm 4.01) \mu \mathrm{g} / \mathrm{kg}$ respectively.

Table 3, indicated that the use of endosulfan in southsouth Nigeria is not as popular as aldrin and heptachlor epoxide, endosulfan was detected in only eight markets (less than half) compared to a total of eighteen markets evaluated. Aldrin was detected in cowpeas collected from seventeen markets while heptachlor epoxide was observed in cowpeas obtained from twelve markets (two-third). One-fifth (20) of the samples analysed are above the MRL, while about one-half (47) of the samples are below the MRL and in one-fourth of the samples, were not detected. Pesticides were generally used in most south-south markets covered in this study for the preservation of cowpea. In some markets, two or three pesticides were found in a cowpea sample, this could be due to the addition of one of the pesticide before the transportation of the cowpea and the other during the storage in the warehouses. 
Table 1. Validation Data of Experiment.

\begin{tabular}{|c|c|c|c|c|c|c|c|}
\hline Pesticide & $\mathbf{N}$ & $\begin{array}{c}\text { LOD } \\
(\boldsymbol{\mu g} / \mathbf{k g})\end{array}$ & $\begin{array}{c}\text { LOQ } \\
(\boldsymbol{\mu g} / \mathbf{k g})\end{array}$ & Equation & $\mathbf{R}^{2}$ & $\begin{array}{c}\text { Recovery } \\
(\mathbf{\pm R S D})\end{array}$ & $\begin{array}{c}\text { Precision } \\
( \pm \mathbf{R S D})\end{array}$ \\
\hline Aldrin & 4 & 0.21 & 0.68 & $\mathrm{y}=122450 \mathrm{x}-108325$ & 0.9982 & 94 & 3.2 \\
\hline o,p'-DDT & 4 & 0.14 & 0.47 & $\mathrm{y}=363296 \mathrm{x}-13504$ & 0.9959 & 93 & 3.7 \\
\hline Endosulfan & 4 & 0.17 & 0.56 & $\mathrm{y}=54111 \mathrm{x}-48105$ & 0.9986 & 89 & 4.4 \\
\hline $\begin{array}{c}\text { Heptachlor } \\
\text { epoxide }\end{array}$ & 4 & 0.27 & 0.89 & $\mathrm{y}=151807 \mathrm{x}-128983$ & 0.9980 & 84 & 7.5 \\
\hline $\mathrm{Y}-\mathrm{HCH}$ & 4 & 1.75 & 5.83 & $\mathrm{y}=27650 \mathrm{x}-17226$ & 0.9969 & 104 & 5.3 \\
\hline
\end{tabular}

Table 2. Gas Chromatographic- Mass Spectrometry Analysis for the Organochlorine Pesticides Detected in the Cowpeas.

\begin{tabular}{|c|c|c|c|c|c|}
\hline Pesticide & Range & $\begin{array}{c}\text { Retention Time } \\
\text { (Mean } \pm \text { SD)min. }\end{array}$ & $\begin{array}{c}\text { Quantification } \\
\text { ion }\end{array}$ & $\begin{array}{c}\text { Confirmation } \\
\text { ion }\end{array}$ & Molecular Mass \\
\hline Aldrin & $4.76-4.96$ & $4.85 \pm 0.04$ & 66.00 & 79263 & 365 \\
\hline o,p'-DDT & $6.01-6.43$ & $6.07 \pm 0.07$ & 235.00 & 165236 & 354 \\
\hline Endosulfan & $5.55-5.68$ & $5.62 \pm 0.04$ & 241.00 & 195237 & 407 \\
\hline $\begin{array}{c}\text { Heptachlor } \\
\text { epoxide }\end{array}$ & $5.13-5.39$ & $5.33 \pm 0.06$ & 81.00 & 237353 & 389 \\
\hline Y-HCH & $3.84-3.89$ & $3.85 \pm 0.08$ & 181.00 & 111219 & 291 \\
\hline
\end{tabular}

Table 3. Concentration in $\mu \mathrm{g} / \mathrm{kg}$ of Pesticides in Cowpea Obtained from South-South of Nigeria.

\begin{tabular}{|c|c|c|c|c|c|}
\hline States/Towns & Aldrin & o,p'-DDT & Endosulfan & $\begin{array}{c}\text { Heptachlor } \\
\text { epoxide }\end{array}$ & Y-HCH \\
\hline EDO & & & & & ND \\
\hline Agenebode & $445.076 \pm 6.427$ & $5.21 \pm 0.02$ & ND & $23.80 \pm 1.04$ \\
\hline Ekenwan & ND & ND & $67.7 \pm 18.1$ & $161.3 \pm 81.3$ & ND \\
\hline Illushi & $0.23667 \pm 0.02488$ & $0.11 \pm 0.04$ & $71.29 \pm 7.38$ & $188.84 \pm 3.42$ & ND \\
\hline Lagos street & $0.144 \pm 0.04534$ & ND & ND & ND & ND \\
\hline Aduwawa & $0.084 \pm 0.03803$ & $4.17 \pm 0.61$ & ND & ND & ND \\
\hline DELTA & & & & ND & ND \\
\hline Jakpa & $29.65 \pm 1.94$ & $7.23 \pm 1.10$ & ND & $2.658 \pm 0.1845$ & $23.29 \pm 2.23$ \\
\hline Igbudu & $1.8948 \pm 0.00808$ & $8.96 \pm 0.51$ & ND & $32.34065 \pm 1.102$ & $243.90 \pm 4.01$ \\
\hline Main & $1.791 \pm 0.103$ & $12.41 \pm 3.55$ & ND & & \\
\hline BAYELSA & & & & ND & $41.20 \pm 3.80$ \\
\hline Swali & $1.7202 \pm 0.0789$ & $18.57 \pm 5.22$ & ND & ND & $75.08 \pm 5.71$ \\
\hline Yenagoa & $1.772 \pm 0.149$ & $14.08 \pm 1.43$ & ND & ND & ND \\
\hline Warehouse & $2.2232 \pm 0.0753$ & $12.93 \pm 2.85$ & ND & & \\
\hline RIVERS & & & & & \\
\hline
\end{tabular}




\begin{tabular}{|c|c|c|c|c|c|}
\hline Rumukoro & $1.845 \pm 0.432$ & $10.23 \pm 2.03$ & $107.0 \pm 18.0$ & $10.21 \pm 1.71$ & $144.40 \pm 5.00$ \\
\hline Rumokuta & $2.764 \pm 0.422$ & $13.30 \pm 2.80$ & $111.3 \pm 35.1$ & $7.415 \pm 0.953$ & $53.96 \pm 2.67$ \\
\hline Oil mill & $2.265 \pm 0.288$ & $21.30 \pm 3.6$ & $142.94 \pm 2.05$ & $11.30 \pm 1.31$ & $32.45 \pm 3.85$ \\
\hline AKWA-IBOM & & & & & \\
\hline Oron & $1.853 \pm 0.376$ & $8.46 \pm 1.22$ & ND & $5.048 \pm 0.350$ & $1.13 \pm 0.37$ \\
\hline Tiam & $1.781 \pm 0.253$ & $182.24 \pm 5.13$ & ND & $6.459 \pm 0.329$ & ND \\
\hline $\begin{array}{c}\text { CROSS } \\
\text { RIVER }\end{array}$ & & & & & \\
\hline Ikom main & $1.7337 \pm 0.0938$ & $77.20 \pm 4.40$ & $55.95 \pm 6.35$ & $18.927 \pm 0.324$ & $0.85 \pm 0.34$ \\
\hline Esuk & $1.518 \pm 0.258$ & $110.41 \pm 1.84$ & $56.71 \pm 1.77$ & $6.280 \pm 0.148$ & $3.20 \pm 0.41$ \\
\hline Watt & $1.044 \pm 0.185$ & $169.70 \pm 6.50$ & $39.37 \pm 8.64$ & $52.8 \pm 41.1$ & $4.22 \pm 0.87$ \\
\hline
\end{tabular}

Table 4. Incidence of Occurrence of OCP's in Cowpea Obtained from South-South of Nigeria.

\begin{tabular}{|c|c|c|c|c|}
\hline Pesticides & \multicolumn{4}{|c|}{ Number of samples in this range $(\boldsymbol{\mu g} / \mathbf{k g})$} \\
\hline Aldrin & ND & $<\mathbf{1}$ & $>\mathbf{1}$ but $<$ MRL & $>$ MRL \\
\hline o,p'-DDT & 1 & 3 & 13 & 2 \\
\hline Endosulfan & 2 & 1 & 11 & 5 \\
\hline Heptachlor epoxide & 11 & 0 & 7 & 1 \\
\hline $\mathrm{y}^{-} \mathrm{HCH}$ & 7 & 0 & 8 & 4 \\
\hline
\end{tabular}

$\mathrm{ND}=$ Not detected

\section{DISCUSSION}

The results have shown a wide range of concentrations in different states, indicating a high level of indiscriminate addition of these organochlorine pesticides to cowpea, this could cause serious health problems following its ingestion. Acute poisoning symptoms [19] and deaths have been reported due to high concentrations of pesticides and some of these may have remained largely undocumented, while repeated intake of pesticide laden cowpeas have been reported to cause irreparable damages in different organs [20].

MRL set by EU provides the highest level of these pesticides that is allowed in food items. The half-life of these pesticides allows them to remain on the cowpeas for more than one farming season. This is a course for concern since cowpeas are eaten daily in some household as an alternative and cheap source of protein.
The importance of pesticides to cowpea production cannot be over-emphasised, but a consistent report of high concentration of pesticides from studies done in sub-Saharan Africa [18], has become a matter of public health significance. The consumption of cowpeas or its delicacies laden with high levels of $\mathrm{Y}^{-}$ hexachlorocyclohexane (Gammallin) could produce different central nervous system disorders, gastrointestinal effect and death in some cases. Cowpeas area rich source of protein cultivated and consumed daily in sub-Saharan Africa in place of animal proteins that are expensive[21].

Although these pesticides may break down overtime, their metabolic products could be more active than the pesticides. The presence of these metabolites could give a clue as to when the pesticides were applied [22]. Detection of pesticides in cowpeas justifies the need for regular monitoring of cowpeas by regulatory agencies and the need for sensitisation 
of both the farmers and merchants on the danger of using these pesticides in food preservation.

\section{CONCLUSION}

Organochlorine pesticides are used in most of the markets in South-South Nigeria for the preservation of cowpeas and in some cases, two or more were detected in a given sample, which could be due to the addition of a combination of pesticides. The need for regular monitoring by regulatory agencies and for sensitisation of both the farmers and merchants on the danger of using these pesticides in cowpeas preservation is therefore germane

\section{REFERENCES}

1. Mahmood I, Imadi SR, Shazadi K, Gul A, Hakeem KR. Effects of pesticides on environment. InPlant, soil and microbes 2016 (pp. 253-269). Springer, Cham.. doi: 10.1007/978-3-319-27455-3_13.

2. Zacharia JT. Identity, physical and chemical properties of pesticides. Pesticides in the modern world-trends in pesticides analysis. 2011:1-8.. doi:10.5772/17513.

3. Sosan MB, Oyekunle JA, Olufade YA. Dichlorodiphenyl-trichloro-ethane (DDT) and hexachlorohexane $(\mathrm{HCH})$ pesticide residues in foodstuffs from markets in lle-lfe, Nigeria. International Journal of Biological and Chemical Sciences. 2015;9(1):442-53.. doi: 10.4314/ijbcs.v9i1.38.

4. Singh Z, Kaur J, Kaur R, Hundal SS. Toxic effects of organochlorine pesticides: a review. Am. J. BioSci. 2016;4(3):11..doi: 10.11648/j.ajbio.s.2016040301.13.

5. Prato M, Polimeni M, Giribaldi G. DDT as antimalaria tool: the bull in the China shop or the elephant in the room?. Insecticides-Development of Safer and More Effective Technologies. 2013.http://dx.doi.org/10.5772/53241

6. Helander B, Olsson A, Bignert A, Asplund L, Litzén $K$. The role of DDE, PCB, coplanar PCB and eggshell parameters for reproduction in the whitetailed sea eagle (Haliaeetus albicilla) in Sweden. Ambio. 2002:386-403.doi: 10.1579/0044-744731.5.386.

7. Bolor VK, Boadi NO, Borquaye LS, Afful S. Human risk assessment of organochlorine pesticide residues in vegetables from Kumasi, Ghana. Journal of Chemistry. 2018;2018.https://doi.org/10.1155/2018/3269065
8. Sakine UK. Insecticide Resistance, InsecticidesAdvances in Integrated Pest Management, Dr. Farzana Perveen (Ed.). 2012.doi: 10.5772/28086. Available from: https://www.intechopen.com/books/insecticidesadvances-in-integrated-pestmanagement/insecticide-resistance

9. Reigart JR, Roberts JR. Recognition and management of pesticide poisonings. US Environmental Protection Agency; 1999. Available electronically on Internet at: http://www.epa.gov/pesticides/safety/healthcare

10. Genuis SJ, Lane K, Birkholz D. Human elimination of organochlorine pesticides: blood, urine, and sweat study. BioMed Research International. 2016;2016. .https://doi.org/10.1155/2016/1624643

11. Nahas AA, Reem MZ, Gamila AM, Ahmed AG. Oxidative Stress and Apoptosis Biomarkers in Neonate Rats' Brain Exposed to Diquat during Lactation. Egyptian Journal of Hospital Medicine. 2019;77(6). doi:10.4172/2476-2067.1000122

12. Sharma D, Nagpal A, Pakade YB, Katnoria JK. Analytical methods for estimation of organophosphorus pesticide residues in fruits and vegetables: A review. Talanta. 2010;82(4):107789.doi: 10.1016/j.talanta.

13. Olufade YA, Sosan MB, Oyekunle JA. Levels of organochlorine insecticide residues in cowpea grains and dried yam chips from markets in lle-lfe, Southwestern Nigeria: a preliminary survey. Ife Journal of Science. 2014;16(2):16170..doi:10.4314/IJS.V16I2

14. Iya IB, Kwaghe TT. The economic effect of spray pesticides on cowpea (Vigna unguculata L. Walp.) production in Adamawa state of Nigeria. Int. J. Agric. Res. 2007;2:64750..doi:10.3923/ijar.2007.647.650.

15. Singh BB, Ehlers JD, Sharma B, Freire Filho FR. Recent progress in cowpea breeding. FATOKUN, CA; TARAWALI, SA; SINGH, BB; KORMAWA, PM. 2002:22-40.

16. Oyekunle JA, Ogunfowokan AO, Torto N, Akanni MS. Determination of organochlorine pesticides in the agricultural soil of Oke-Osun farm settlement, Osogbo, Nigeria. Environmental monitoring and assessment. 2011;177(1-4):5161.https://doi.org/10.1007/s10661-010-1617-y.

17. Sonchieu J, Srivastava AK, Ngassoum BM, Tchatchueng JB, Srivastava LP. Contamination of cowpea (Vignaunguiculata (L.) Walp) and derived products by residues of banned pesticides in Cameroon: Health risk estimation. J. Pestic. 2017;104:147-60. 
18. Germany PA. Pesticide and Health Hazards: Facts and Figures. Hamburg, Germany: PAN Germany_Pestizid Aktions-Netzwerk eV. 2012.

19. Ojo J. Pesticides use and health in Nigeria. Ife Journal of Science. 2016;18(4):981-91..

20. Osho, S.M., Dashiell, K.. Expanding soybean production, processing and utilization in Africa. GTZ. Post-Harvest Systems. The newsletter for post-harvest systems development in Africa No. 1.1997 (also available atwww.iita.org/info/ph/mar974.htm).

21. Ahmed FE. Analyses of pesticides and their metabolites in foods and drinks. TrAC Trends in Analytical Chemistry. 2001;20(11):649-61.. https://doi.org/10.1016/S0165-9936(01)00121-2. 